\title{
Effectiveness Of Heads Of Schools In Supervising Teachers' Teaching Activities In Secondary Schools In Kagera Region, Tanzania
}

\author{
Adolphina Mwesiga (Sr.)* Evans Ogoti Okendo (Phd) ** \\ * PhD Candidate Mwenge Catholic University (Tanzania) \\ **Mwenge Catholic University (Tanzania), Faculty of Education
}

\begin{abstract}
Head of schools are considered imperative in education system for influencing teachers' teaching commitment to improve school performance and attaining quality education. This necessitated the need of this study to investigate the effectiveness of heads of schools in supervising teachers' teaching activities in secondary schools in Kagera region. The study was guided by transformational theory. The reviewed literatures indicated the availability of several studies on school leadership and commitment of teachers as factors for school performance. However, still there was a need for investigating the effectiveness of school headship in supervising teachers' teaching activities in secondary schools as central variables for effective teaching in secondary schools, due to persisting challenges constrains on leadership effectiveness and education performance. The study employed convergent parallel design from mixed research approach. The target population of the study included all head of schools, academic masters/mistress and teachers in public secondary schools in Kagera region. The sample size comprised 32 schools, 32 head of schools, 32 academic masters/mistress and310 teachers. Probability and nonprobability sampling techniques used to sample participants. Instruments for data collection were questionnaires, interview guide and document analysis guide. The study carried out a piloting study into two schools; comprising ten (10) participants. Content validity was established to ensure the validity of instruments, split half method used to ascertain the reliability of questionnaire, dependability and credibility determined the reliability of interview guide. Descriptive statistics used to analyze quantitative data and thematic analysis used for qualitative data analysis. Hypotheses were tested by Pearson Correlation. Results suggest strong significant relationship between school headship and teachers teaching commitment.
\end{abstract}

Keywords: Teachers' profession commitment, Transformational leadership and Effectiveness of school headship

\section{Introduction:}

Leadership in education is a central factor for strengthening education system and achieving quality education of the nation (Toner, 2015; Wolhuter, Van der walt; \&Steyn, 2016). Thus, roles and accountability of leadership in many countries, especially developing countries have been considered imperative for providing quality education basing on school performance and effective outcomes (UNESCO, 2016). This is a reason why leadership is recognized as an important aspect in the system of education for facilitating successful implementation of curricula, programmes, and attainment of educational goals in the course of school performance (Harris, Day, Hadfield, Hopkins, Hargreaves, \& Chapman, 2013; Hallinger, Heck, \& Murphy, 2013; Agi, Levidoe,
\&Antony 2016). The global economy, world market competition and technological development, also requires quality and standard education, highly skilled workforce and competent personnel as a result of education which are the product of effective leadership especially at a school level (Supovitz, 2014; UNESCO, 2016). The effectiveness of educational leadership normally depends on leaders' ability of influencing, encouraging and helping followers to work towards the achievement of the intended education results.

Several researchers have indicated that educational leadership in many countries is expected to improve students' academic performance, teachers' commitment, performance and accountability; bringing changes in education system and seeking an internationally competitive labour force (URT, 
2008, ; Gyasi, Baox, \& Ampomah, 2016; Chen, Cheng \& Sato, 2016; Wolhuter, van der Walt, Steyn, 2016). The Organization for Economic Cooperation and Development (OECD, 2014) enlarged the meaning of leadership from practice point of view to policy perspectives, believing that educational leadership policy would contribute to quality and effective leadership, if it would be considered as professional with the requirement of training, acquiring knowledge and skills. Thus, leadership in education ought to be measured in terms of education outcomes.

In this respect countries have developed different policies to guide the education system for having effective and skilled education leaders. In European nations, and United States focused on developing policies which would generate quality leadership for quality education (Supovitz, 2014). In England and Scotland they have even a formal system of certifying, licensing and crediting leaders' ability and skills (Asuga, Eacott, \&Scevak, 2014).

In the earliest of 1960 s, up to 1980 s education system around countries has been centralized on the base of nation accountability. Issues concerning curriculum setting, policy making, training, finance and resources management, programme implementation and management of all educational issues were the responsibility of central governments (URT, 1995; McGinn\& Welsh, 1999; Kuluchumila, 2014; Supovitz, 2014). In this aspect, issues like planning, budgeting, policy development, education reforms and decisions were dominated by the government, with top-down system of management.

In the context of Africa things were not different from global system. From time before and immediately after independent, education system in African countries was centralized managed with aspect top-down system of leadership (Kuluchumila, 2014; Sesay, 2014). Countries like Uganda, Nigeria, Ghana, South Africa and many others were pointed as an example. In particular, education system of Tanzania from 1960s education management was centralized and the government had dominated all the education provision and process. Schools, colleges, universities and vocational trainings were directly managed and operated directly from the Ministry of Education and Culture (MoEC) whereby all decisions had to be done at a national level while at school level had to receive directives from above with limited authority (URT, 1995).
From 1970s the world education phenomena changed to decentralization policy in achieving quality education as a demand of global economy. According to McGunn\& Welsh (1999), education decentralization was a gradual change which went hand in hand with political debates, economic change, population growth and impact of technological development worldwide. This necessitated a new focus around countries including Tanzania whereby in Tanzania the policy of Decentralization by Devolution policy was introduced in 1998 to comply with this trend (URT, 2010). The policy placed up the delegation of power at all levels known as regional, districts, schools and wards; each level carries distinct functions and responsibilities. It aimed at enabling individual schools, and leaders to deliver quality education, approve changes in their areas of jurisdictions, adopt effective management of schools and make decisions, plans on their schools.

At the apex level, the Ministry of education remained as the overall supervisors and advisers concerning educational decisions and activities at local levels (URT, 2004). They are responsible with policy and curriculum formulation, education programmes planning, supervision, monitoring, overseeing the implementation at local levels, and ensuring standards and quality education delivery. At a school level school leaders are vested with the overall responsibility of ensuring successful implementation of curriculum and school programmes, supervising and monitoring day to day activities of teaching and learning, motivating teachers, and ensuring their commitment and school performance among other responsibilities.

This situation leads to the demand of strong school leaders in several aspects like authority and autonomy, training, inducements and other support from the government. In handling the issues initiatives have been done in responding to the demand of leadership in education. For example, the government introduced the Agency of Development of Education Management (ADEM) to equip school leaders with needed knowledge, skills and ability for effective management of school activities and programmes. Again, school leaders have been introduced with guiding documents known as School Improvement Toolkit (SIT), which aims at guiding school leaders in solving school challenges (URT, 2013). Moreover, several programmes are conducted under Tanzania Heads of Secondary Schools Association (TAHOSSA), Tanzania Education Network (TEN), School Committee Capacity Development (SCCD), 
Haki Elimu, and many others (URT, 2001; Malekela, 2004; Kuluchumila, 2014).

This is intentionally done to guide and strengthen leadership at school levels towards the achievement of educational goals, improving school performance and attaining quality education which is expected to be a fundamental to Tanzania's development. On top of that, head of school is obliged to motivate, support and guide teachers work effectively to improve quality of teaching (Emmanouil, Osia, \& Paraskevi-Ioanna, 2014). An effective teacher' is a remarkable factor which predicts effective performance in education, and teachers' commitment is one of the key propellers in achieving the goal. In this fact, head of school is responsible to foster teachers' commitment as to ensure their effectiveness.

Committed teachers are determinants of quality education and academic performance of students or schools. Once Nyerere (1975) in Lema, Mbilinyi, \&Rajani, R. (2004) said, "Children are, because teachers are." Liston, \&Zeichner, (2013) reinforced the idea that, teaching is more than a noble profession. The global world determines teachers as prime movers in implementing curriculum and teaching/learning (Duze, 2012). In this regard, teachers' commitment is a significant aspect for achieving quality education. Kunter et al, (2013) states that, the success of education is routed on teaching professional competence and commitment basing on teachers skills, knowledge, attitudes and values, as well as their accountability on effective teaching which can be measured in terms of their school performance. For this fact, school leaders' effectiveness in the context of improving academic performance and quality education in schools would be the result of fostering teachers' commitment.

However, teachers' commitment in Tanzania has been an issue of discussion due to the reason that the expected results from education or schools are not effectively produced, considering the mentioned indicators of performance. For example, Poor performance of students and schools in national examination for several years that most students are getting marginal pass of Division IV or failing completely (Mkumbo, 2012; Twaweza, 2013; BEST, 2012-2016). It was also noted that, from five past years there was no significant improvement regarding the issue of students lacking basic skills of reading, writing, and arithmetic (Uwezo, 2010, 2015 \& 2016).

Teacher Service Department (TSD), (2007) found that teachers' misconduct was among the serious hindering factor for teachers' commitment and teaching below the expected standard. Issues underlying teachers' misconducts include; absenteeism, sexual abuse, drunkenness, examination fraud, and unethical dressing (Amani, 2014; Dassan \& Sima, 2017). For example a recent report (Twaweza, 2016), revealed the issue of teachers absenteeism to be high, ranging from $11 \%$ to $30 \%$ as the attendance rates in schools and class attendance in Kenya, Tanzania and Uganda, while Tanzania's rates being above all three countries with $25 \%$ low attendance.

Basically, head of schools are accountable to enhance the commitment of teachers' professional responsibilities, commitment, and accountability in teaching. Studies and education documents show that the primary role of head of school is to supervise teaching and learning activities and monitoring the implementation of the work of teachers (URT, 2013; Ugwu, 2015; Kor \& Opare, 2017).

They must ensure conducive teaching and learning environment, and effective teaching and learning activities, including effective use of time on the task for the entire school days, compliance of professional codes of ethics and conducts, school rules and regulations, and teaching preparations (URT, 2010); hence teachers' commitment.

Despite the delegated power to head of schools as indicated above, still the effectiveness of head of schools in the context of fostering teachers' commitment is questionable, as Mkumbo, (2012) found that teachers' commitment to the teaching profession is overwhelmingly low. In relation to that, the mentioned factors like; poor students' academic performance, and teachers' misconduct, indicates the prevailing challenge of uncommitted teachers in secondary schools. This raises the question for discussion of whether head of schools are aware of this challenge. Also, their ability for running schools, responsibilities and efforts in ensuring that teachers' commitment is met..

\section{Statement of the problem}

Headship in education plays a central role for successful implementation of educational policies, curriculum and all education programmes concerning the achievement of academic performance and attainment of quality education in line with the Sustainable Development Goals (SDGs) (URT, 2014). To achieve this, effective head of schools are required for effective management of schools, alongside with teachers who are dedicated to professional commitment to 
ensure effective teaching and learning. Thus, underperformance apparently manifested in schools for quite number of years, whereby students perform poorly and got marginal pass of division IV or failed completely (Mkumbo, 2012; Twaweza, 2013; BEST, 2012-2016), would be directly related to both headship and teachers ineffective management of schools and teaching.

Moreover, the way head of schools foster teachers commitment was considered a question of discussion. Teachers' misconducts on the other hand reviewed as challenge for effective teaching. For example, the low attendance rate of teachers is reported to be $10 \%$ to $13 \%$ in primary and secondary schools, (Twaweza, 2011; Betweli, 2013; Bilinga \& Mfaume, 2016). The fact that teachers are not observing professional codes of ethics and conducts their devotion to students and their performance might be jeopardized. There has been a little focus in assessing the effectiveness of school heads of schools in supervising teaching effectiveness as a key factor for achievement in schools and attainment of quality education in secondary schools. Therefore, this was the focus of this study

\section{Literature review:}

School headship is a key aspect in education system as it plays a crucial role in achieving intended goals of education. It is therefore, defined as a process whereby the school leader struggle to fulfil their position roles including the influence of his/her teachers to participate in the implementation of curricula, education programmes, school activities and improves students' academic performance (Gebreselassie, 2015). Thus, the successful implementation of education programmes, policies and strategic plans will always depend on effectiveness of leadership in schools. This is supported by Cyprès, \&Breckner (2013), who argued that "great schools do never exist apart from leaders."

A school leader is also recognized as chief executive in improving schools and achieving significant results in education. Effective school leader should be responsible, answerable, and committed to communicate the school vision, mission and goals, developing school strategic plans, monitor teachers, students teaching and learning activities, and motivating teachers and students by providing them with proper teaching and learning materials. Either, they are supposed to create conducive environment that teaching and learning can take place effectively (Rajbhandari,
2014). In order to meet the above aspects there should be critical leaders under specific nature and characteristics. With critical leaders in schools would allow a quick understanding of evaluating all situations as they appear, and thinking critically followers and their needs, communicating the intended results and anticipating the future performance. This would probably allow the building of higher level of influence and credibility.

The main factor for successful school leadership would be determined by the nature of leaders in terms of communication, ability, knowledge and skills, behaviors, flexibility, personality traits and many others. Day \& Sammons (2016) in their study on successful school leadership in UK education, found the important of focusing on leadership nature and characteristics when discussing the issue of effective leadership, so as to affect job satisfaction and performance for teachers, students and successful implementation of education policies.

Their purpose was to provide an overview of the growing body of international literature that examines the nature and purpose of school leadership. They evidenced that school leaders have the key role to play in setting directions, and creating a positive school culture, including proactive school mindset, supporting and enhancing staff motivation and commitment. They came up to the conclusion that, an effective leadership is characterized with the application of instructional and transformational leadership which deals with teaching process, in and out classrooms and promoting better academic outcome. The study had deficient of what makes leaders effective, there many aspect which would indicate leadership effectiveness, in this case issues like leadership skills, knowledge and personal ability. One would have to question on; is it leadership behaviour of accountability to their leadership roles that makes a leader effective or something else. However, this study focused on transformational leadership looking on how school leaders influence teachers' commitment in relation to their ability of achieving supervisory role. The practice of transformational leadership in school headship and for the matter of effective teaching seem imperative in improving education results in the sense that effective leaders transforms matters in day to day teaching activities.

Many studies assume that the use of instructional and transformational leadership approaches would increase the level of organizational commitment and job satisfaction (Uysal, Aydin, \&Sarier, 2013). A comparative study conducted by Chen, Cheng \& 
Sato, (2016) on effects of school principals' leadership behaviors between Taiwan and Japan. The study analyzed leadership behaviour and its impact on school effectiveness. The findings of the study found that Japan has stronger leadership with instructional leadership behaviour in comparison to Taiwan, which base on their culture-related. They recommended that, to achieve school effectiveness, teachers' job performance, and teachers' organizational commitment instructional leadership behavior should be adopted.

In relation to this, the current study did not rely much on the review to trust leadership styles only as determinants for successful school leadership, instead other factors were considered. For example, effect of education policy, leadership training, effective supervision, monitoring and evaluation of teaching activities and other factors which affects leaders for their effectiveness. For example, competent leaders as mentioned in the above aspects, would require appropriate knowledge and skills, and be aware of their leadership roles. This would likely help leaders perform their leadership effectively and influence followers attention to commitment. However, the effectiveness of leadership in schools should not be confined to leadership styles as in Chen et al, but the all situation of instructional and managerial roles which was assumed to be collectively in the aspect of transformational leaders, limited to its critical element of transformations. This was particularly meant to address a global rapid change which demands graduates who can fit to world workforce. From this aspect therefore, school leadership is needed to transform schools into higher level of performance by means of building a higher level of teachers' commitment.

Currently, there has been a global increase demand of education performance, quality education and world market requirement of personnel, while the expectation of parents and education stakeholders on good product of education becoming their sake. From this standpoint countries and or governments become obliged in strengthening education system and prepare their people who can fit in this scenario, as necessitated. Thus, studies concentrate on diversity aspects towards the issue.

Duze (2012), on his study of the changing role of school leadership and teacher capacity building in teaching and learning in Nigeria, found the importance of school leadership in today's global world in building teachers' capacity and make theme fit and cope the world development. A successful leader will have to focus largely on technical aspect needs as a paradigm shift towards great focus of human development. According to the study leaders are potential in fostering teachers fulfill their responsibility. However, Duzes' perspective is that leaders need to adopt an instructional leadership as a strategy that can enhance teachers' capacity under which relevant and compulsory programmes must be introduced for aspiring and serving school teachers. These leaders can set clear goals, managing curriculum, monitoring and evaluating lesson plans and scheme of works, and supervising daily school activities and teachers teaching works. The most important thing the study put forward is to develop a teacher leadership rapport to improve learning and knowledge sharing effectively and efficiently. Despite the study perspective of changing role for school leadership as a focus on instructional leadership, there must be consensus regarding the important components of what makes a leader competent or successful. For example level of training, quality of leadership, autonomy and support which might hinder effectiveness of leadership. A transformational leaders was the best focus of this study with believe that it combines all issues. From the concept of a "master manager" as addressed by Quinn (1988) the ability of a transformational leaders is the use of all leadership behaviors when they are needed.

Other scholars, (Day \& Sammons 2016; Swamy \& Swam, 2014) supports that, if leaders are ambitious to effective achievement will be mostly confined on their instructional role which guides them involve in setting clear vision and goals, allocating resources to instruction, planning and managing the curriculum, decision making, monitoring lesson plans, and evaluating teachers' teaching and trust the staff to reach their goals and give full play for staff's potential. Furthermore, a complexity change of education is no longer avoided, it now forces everyone in this field to rethink about education goals implementation currently and for future, making comparison on demands of what everyone should know, learn and hold, for revolutionary changes in education. It is an issue of mandate for education stakeholders to consider changes in education which demand capacity building of teachers and leaders, collaboration and acknowledging technological use in teaching and learning process.

Zaka (2013) in his study conducted in New Zealand on a case study of implementing the blended teaching and learning as a teaching approach in New Zealand secondary schools, aimed at 
examining the complexity of blended teaching and learning approach implementation by researching the roles of students, teachers, school leaders and other educational stakeholders. The findings indicated that, the introduced new approach of facilitating students-centered learning was effectively implemented because of principals (school leader). Teachers were very committed, ready and interested on the programme, also students and parents cooperated in the programme. $\mathrm{He}$ further recognized readiness of education stakeholders in News land to be a strong weapon for this success.

The study further investigating the challenges faced the programme, and found that not all teachers were willingly with the teaching approach, and some had very little knowledge on it. He finally suggests that, school leaders must play their vital role of building teachers capacity and interest on the new approach, as well as theoretical and practical seminars for school leaders. I agree with Zaka's study (2013), that teachers should be provided with in-school professional development opportunities, seminars, workshops, and regular consultations, without ignoring leadership skills, efforts, competence and role played on teacher motivation, leading to teacher retention, and school performance, maintenance and teaching commitment. The observed challenges would be resolved with the practice of transformational leader who is normally obliged to influence intellectual stimulation in updating followers' knowledge and skills.

A study conducted by Wolhuter, Van der Walt \& Steyn (2016) in South Africa on a strategy to support educational leaders in developing countries to manage contextual challenges. Focus group discussion was conducted, purposive sampling was adopted and the target population based on community as a whole and not school based. The study pointed out three sets of contextual forces important for a leader to take into account. Such as Such as; the contours of the education system in which school leadership, organizational change and development occur; societal and international contexts. Results maintained that education leaders in developing countries need to understand the contextual factor impacting on their future as education leaders which would support them employ an effective strategy of dealing with complex challenges of the future. On the other hand, Kuluchumula (2012); and Yariv, (2011) indicated the alarming challenge in educational leadership, as lack of leadership skills as the external source of weak performance. This indicates a remarkable challenge of poor management skills and inadequate supervision in schools which results to the failure of dealing with school issues and teachers' difficulties. The quality of school achievement depends largely on the competence of school leadership, implying the importance need of leadership training before holding such position.

Acquiring leadership skills is to enable leaders solve educational challenges, and deal with stakeholders especially teachers and their professionalism effectively. It is difficult to confirm exactly if leadership training is a global challenge or the issue of few countries. In general this might be a serious challenge where leaders are not trained, and where leadership development programmes is likely not considered as important. Tanzania is among the countries facing this challenge in some extent, where even the appointment of head of school depend much on experienced teacher rather that knowledge, skill and abilities (Komba\&Nkumbi, 2009).

However, providing school leaders with required skills must not be disregarded. Thus, there should be special programmes for leadership training and development. Under such circumstances school leaders, teachers, students and other workers are expected to perform well, as a result of effective school leaders who are capable and confidence to influence follower (Musa, 2014). Teachers' commitment on the other hand is possible when leaders have ability of influencing them. This could mean that teachers normally become what head of schools make them to be. In the same line of thought, Boyd, Grossman, Ing, Lankford \& Wyckoff (2009) attempted to investigation the reason for a serious challenge of teachers turnover in the United States which was ranging to $84 \%$ of teachers leaving the profession yearly. A study observed the influence of school administrators as a main factor on teachers' retentions decisions. The findings provided evidence that the school administrators is an important factor in teacher retention decisions, in a sense that maintenance of teachers in their profession is confined to their leaders' role in terms of motivations, work recognition, job satisfaction, security, training and the like. The study however, could have indicated more on the important roles of school administrators in influencing their workers retentions. This study considered the important role of head of schools in relation to their teachers, it was therefore attentively to investigate the extent head of schools perform the supervisory roles to 
influence teachers in terms of their teaching profession

\section{Methodology:}

The study employed the convergent parallel design, focusing on collecting, analyzing, and merging qualitative and quantitative data and results at one time. In this case, the quantitative and qualitative strands was conducted concurrently but independently. The quantitative strand was used to collect data from teachers, on practices of teaching and the actual levels on their commitment as per teaching profession. Qualitative on the other hand was employed to understand the reality of head of schools, on their experiences, and leadership practices in improving teachers' commitment. The target population of the study included head of schools, academic masters and teachers in secondary schools, in Kagera Religion. A sample of 352 participants was drawn from a total number of 3961, which is around ten percent of the entire population. A study sample comprised 32 head of schools, 32 academic masters and 288 teachers, with a total of 352 . Both probability and nonprobability sampling procedures were used to select participants of the study. The study utilized questionnaires, interview guide, and document analysis guide for data collection.

\section{Discussion of findings:}

\section{Head of Schools Supervision of Teachers' Teaching Activities in Secondary School:}

The study sought to find out the effectiveness of head of schools in fostering teachers' teaching professional commitment through their supervisory roles of teaching activities of teachers. As per the Ministry of Education, head of schools are determined as the main actors in school supervision (URT, 2009). Head of schools are accountable with teachers' professional responsibilities and accountability in teaching. The study therefore sought to investigate whether head of schools perform their responsibilities effectively in terms of supervising the day to day activities of teachers to foster their professional commitment. The responses were summarized and presented in Table 1

Table 1 Teachers' Responses on HoS Supervising Teaching Activities in Secondary Schools (N=288).

\begin{tabular}{|l|l|l|l|l|l|l|}
\hline HoS Normally used to; & SD (\%) & $\mathbf{D}(\%)$ & $\mathbf{U}(\%)$ & $\mathbf{A}(\%)$ & SA (\%) & $\begin{array}{l}\text { Mean(SD } \\
\text { (\%) }\end{array}$ \\
\hline $\begin{array}{l}\text { Check teachers' preparation of scheme of } \\
\text { works and lesson plans. }\end{array}$ & $18(6.3)$ & $48(16.7)$ & $13(4.5)$ & $172(59.7)$ & $37(12.8)$ & $3.56(1.10)$ \\
\hline $\begin{array}{l}\text { Check teachers' less on notes. } \\
\text { Visit to the classrooms to observe teachers } \\
\text { lesson presentation and issuing sound } \\
\text { feedback. }\end{array}$ & $5(1.7)$ & $37(12.8)$ & $85(29.5)$ & $67(23.3)$ & $94(32.6)$ & $3.72(1.10)$ \\
\hline $\begin{array}{l}\text { Observe teachers attendance and } \\
\text { punctuality in school and class } \\
\text { attendances. }\end{array}$ & $87(30.2)$ & $13(4.5)$ & $30(10.4)$ & $153(53.1)$ & $3.83(1.39)$ \\
\hline $\begin{array}{l}\text { Check students exercises to find out } \\
\text { teachers' output of work. }\end{array}$ & $5(1.7)$ & $46(16.0)$ & $67(23.3)$ & $38(13.2)$ & $132(45.8)$ & $3.85(1.21)$ \\
\hline $\begin{array}{l}\text { Inspect pupils' assessment record books to } \\
\text { find out how teachers make use of } \\
\text { continuous assessment records. }\end{array}$ & - & $59(20.5)$ & $39(13.5)$ & $82(28.5)$ & $108(37.5)$ & $3.83(1.14)$ \\
\hline $\begin{array}{l}\text { Visits to the students play grounds and } \\
\text { other extra curricula activities. }\end{array}$ & - & $41(14.2)$ & $10(3.5)$ & $34(11.8)$ & $203(70.5)$ & $4.39(1.08)$ \\
\hline Keep teachers' attendance/reporting book & - & - & - & $96(33.3)$ & $192(66.7)$ & $4.67(0.47)$ \\
\hline $\begin{array}{l}\text { Ensure teachers accomplishment of } \\
\text { syllabus on time }\end{array}$ & - & $41(14.2)$ & $33(11.5)$ & $58(20.1)$ & $156(54.2)$ & $4.14(1.10)$ \\
\hline Give evaluation feedback to teachers & - & $46(16.0)$ & $46(16.0)$ & $64(22.2)$ & $132(45.8)$ & $3.98(1.12)$ \\
\hline $\begin{array}{l}\text { Holding meeting for teaching evaluation } \\
\text { to gather with teachers }\end{array}$ & - & $46(16.0)$ & $15(5.2)$ & $38(13.2)$ & $189(45.6)$ & $4.28(1.13)$ \\
\hline
\end{tabular}

Source: Flied Data 2018 


\begin{tabular}{lrr}
\hline SA(5)=Strongly & Agree, & $\mathrm{A}(4)=$ Agree, \\
$\mathrm{U}(3)=$ Undecided, & $\mathrm{D}(2)=$ Disagree & and \\
$\mathrm{SD}(1)=$ Strongly Disagree &
\end{tabular}

Results in Table 1 show that majority of teachers are aware of head of schools' responsibilities of supervising teachers teaching activities. For example, teachers agreed that head of schools check teachers' preparation of scheme of works and lesson plans $172(59.7 \%)$, visit to the classrooms to observe teachers lesson presentation and issuing sound feedback, 153(53.1\%), observe teachers' attendance and punctuality in school and class attendances $155(53.8 \%)$, check students' exercises to find out teachers' output of work 132(45.8\%), inspect pupils' assessment record books to find out how teachers make use of continuous assessment records $108(37.5 \%)$, visits to the students play grounds and other extra curricula activities 203(70.5\%), keep teachers' attendance/log book 192(66.7\%), ensure teachers accomplishment of syllabus on time $156(54.2 \%)$, give evaluation feedback to teachers $132(45.8 \%)$, and holding meeting for teaching evaluation together with teachers 189(45.6\%).

The Ministry of Education in Tanzania trust head of schools as the most important element for improving school performance and attaining quality education through their leadership roles, especially supervisory role to ensure successful implementation of curricula. Therefore supervising teachers' teaching responsibilities becomes a core function of head of schools. From the above findings it can be argued that head of schools are effective in terms of supervising, guiding, observing and evaluating teachers' teaching practices and the teaching and learning process in and outside classrooms. The study is in contrary with a study conducted in Uganda by Madunda, Onen, Musaazi \& Oonyu, (2016) which revealed that head of schools in Uganda were ineffective in supervising teachers teaching activities and the consequences teachers were not committed to teach which lead to poor performance. For instance, Teachers were not committed in preparing lesson plans, scheme of work and lesson notes. From teachers responses therefore, the study came to conclude that poor commitment of teachers may be attributed by ineffective head of schools, in relation to poor or ineffective supervision of teaching activities, whereas teachers lack opportunity of recognizing areas of their weakness.

The findings on the other hand concurred with the transformation leadership theory with the view that an effective leader accomplishes supervisory roles and ensure effective and efficiency of subordinates. In so doing the study came to believe that the effectiveness of head of schools revealed from teachers strives teachers to their professional commitment in secondary schools.

\section{Academic Masters/mistress and Head of Departments Supervising Teaching Activities in Secondary Schools}

The study though to found out the extent to which head of schools delegates power to their immediate supervisors in school activities as delegation is a main factor of an effective leader. Academic masters are important figures in secondary schools as academic issues as concerned. Head of department also are appointed to perform duties for particular subjects and teachers workload on subjects they teach. Therefore, head of schools delegate supervisory responsibilities to academic masters and head of departments to deal with teachers teaching activities. Teachers therefore, were required to indicate the extent of their awareness on whether academic master and head of departments perform supervisory duties, and fulfil their responsibilities effectively. The results are as presented in table 2 and Table 3

Table 2 Responses of teachers on Academic Masters Supervising Teaching Activities in Secondary Schools $(N=288)$

\begin{tabular}{|l|l|l|l|l|l|l|}
\hline Academic Masters used to; & SD (\%) & $\mathbf{D}(\%)$ & $\mathbf{U}(\boldsymbol{\%})$ & $\mathbf{A}(\boldsymbol{\%})$ & SA (\%) & Mean(SD) \\
\hline $\begin{array}{l}\text { Check teachers' preparation of scheme } \\
\text { of works and lesson plans. }\end{array}$ & - & - & $10(3.5)$ & $108(37.5)$ & $170(59.0)$ & $4.56(0.56)$ \\
\hline Check teachers' less on notes. & $10(3.5)$ & $41(14.2)$ & $18(6.3)$ & $85(29.5)$ & $134(46.5)$ & $4.01(1.19)$ \\
\hline $\begin{array}{l}\text { Visit to the classrooms to observe } \\
\text { teachers lesson presentation and issuing } \\
\text { sound feedback. }\end{array}$ & $28(9.7)$ & $39(13.5)$ & $49(17.0)$ & $115(39.9)$ & $57(19.8)$ & $3.47(1.23)$ \\
\hline $\begin{array}{l}\text { Observe teachers attendance and } \\
\text { punctuality in school and class } \\
\text { attendances. 23(8.0) }\end{array}$ & $39(13.5)$ & $18(6.3)$ & $59(20.5)$ & $149(51.7)$ & $3.94(1.36)$ \\
\hline
\end{tabular}




\begin{tabular}{|l|l|l|l|l|l|l|}
\hline $\begin{array}{l}\text { Check students exercises to find out } \\
\text { teachers' output of work. }\end{array}$ & $38(13.2)$ & $5(1.7)$ & $86(29.9)$ & $64(22.2)$ & $95(33.0)$ & $3.60(1.32)$ \\
\hline $\begin{array}{l}\text { Inspect pupils' assessment record books } \\
\text { to find out how teachers make use of } \\
\text { continuous assessment records. }\end{array}$ & - & $51(17.7)$ & $5(1.7)$ & $68(23.6)$ & $164(56.9)$ & $4.20(1.12)$ \\
\hline $\begin{array}{l}\text { Visits to the students play grounds and } \\
\text { other extra curricula activities. }\end{array}$ & $5(1.7)$ & $41(14.20$ & $36(12.5)$ & $39(13.5)$ & $167(58.0)$ & $4.12(1.19)$ \\
\hline $\begin{array}{l}\text { Keep teachers attendance/reporting } \\
\text { book }\end{array}$ & $10(3.5)$ & $46(16.0)$ & $68(23.6)$ & $20(6.9)$ & $144(50.0)$ & $3.84(1.29)$ \\
\hline $\begin{array}{l}\text { Ensure teachers accomplishment of } \\
\text { syllabus on time }\end{array}$ & - & $52(18.1)$ & $15(5.2)$ & $67(23.3)$ & $154(53.5)$ & $4.12(1.14)$ \\
\hline Give evaluation feedback to teachers & $5(1.7)$ & $46(16.0)$ & $33(11.5)$ & $38(13.2)$ & $166(57.6)$ & $4.09(1.22)$ \\
\hline $\begin{array}{l}\text { Holding meeting for teaching evaluation } \\
\text { together with teachers }\end{array}$ & $5(1.7)$ & - & $51(17.7)$ & $34(11.8)$ & $198(68.8)$ & $4.28(1.22)$ \\
\hline
\end{tabular}

Source: Flied Data 2018

$\begin{array}{ll}\mathrm{SA}(5)=\text { Strongly } & \text { Agree, } \quad \mathrm{A}(4)=\text { Agree, } \\ \mathrm{U}(3)=\text { Undecided, } & \mathrm{D}(2)=\text { Disagree }\end{array}$ $\mathrm{SD}(1)=$ Strongly Disagree

From Table 2 a considerable number of teachers indicate that they were aware with duties of academic masters in supervising teaching activities in secondary schools. The findings show that teachers agreed and strongly agreed that academic masters in secondary schools Check teachers' preparation of scheme of works and lesson plans 170 (59.0\%), Check teachers' lesson notes 134 (46.5\%), Visit to the classrooms to observe teachers lesson presentation and issuing sound feedback 115 (39.9\%), Observe teachers' attendance and punctuality in school and class attendances 149 (51.7\%), inspect pupils' assessment record books to find out how teachers make use of continuous assessment records 164 (56.9\%), visits to the students play grounds and other extra curricula activities $167 \quad(58.0 \%)$, keep teachers' attendance/reporting book 144 (50.0\%), ensure teachers accomplishment of syllabus on time 154 (53.5\%), give evaluation feedback to teachers 166 $(57.6 \%)$, and holding meeting for teaching evaluation to gather with teachers 198 (68.8\%). Only few teachers agreed that academic masters check students' exercises to find out teachers' output of work $95(33.0 \%)$.

Table 3. Responses of Teachers on Head of Departments on Supervision of Teachers' Teaching Activities $(N=288)$

\begin{tabular}{|l|l|l|l|l|l|}
\hline Responsibilities of head of departments & SD (\%) & $\mathbf{D}(\mathbf{\%})$ & $\mathbf{U}(\boldsymbol{\%})$ & $\mathbf{A ~ ( \% )}$ & $\begin{array}{l}\text { SA } \\
(\boldsymbol{\%})\end{array}$ \\
\hline $\begin{array}{l}\text { Check teachers' preparation of scheme of works and } \\
\text { lesson plans. }\end{array}$ & $15(5.2)$ & $222(77.1)$ & $23(8.0)$ & $28(9.7)$ & - \\
\hline Check teachers' lesson notes. & $18(6.3)$ & $134(46.5)$ & $41(14.2)$ & $83(28.8)$ & $12(4.2)$ \\
\hline $\begin{array}{l}\text { Visit to the classroom to observe teachers lesson } \\
\text { presentation and issuing confidential feedback }\end{array}$ & $10(3.5)$ & $208(72.2)$ & $44(15.3)$ & $19(6.6)$ & $7(2.4)$ \\
\hline Ensure teachers accomplishment of syllabus on time & $38(13.2)$ & $157(54.5)$ & $28(9.7)$ & $44(15.3)$ & $21(7.3)$ \\
\hline $\begin{array}{l}\text { Check students' exercises to find out teachers' output of } \\
\text { work }\end{array}$ & $46(16.0)$ & $146(50.7)$ & $29(10.1)$ & $61(21.2)$ & $6(2.1)$ \\
\hline $\begin{array}{l}\text { Inspect pupils' assessment record books to find out how } \\
\text { teachers make use of continuous assessment records. }\end{array}$ & $38(13.2)$ & $110(38.2)$ & $24(8.3)$ & $99(34.4)$ & $17(5.9)$ \\
\hline $\begin{array}{l}\text { Holding meeting for teaching evaluation together with } \\
\text { teachers }\end{array}$ & $33(11.5)$ & $143(49.7)$ & $27(9.4)$ & $78(27.1)$ & $7(2.4)$ \\
\hline
\end{tabular}

Source: Flied Data 2018 
International Journal of Scientific Research and Management (IJSRM)

||Volume||06||Issue||04||Pages||SH-2018-91-117||2018 ||

Website: www.ijsrm.in ISSN (e): 2321-3418

Index Copernicus value (2015): 57.47, (2016):93.67, DOI: 10.18535/ijsrm/v6i4.sh04

\section{SA(5)=Strongly $\quad$ Agree, $\quad \mathrm{A}(4)=$ Agree, $\mathrm{U}(3)=$ Undecided, $\quad \mathrm{D}(2)=$ Disagree $\quad$ and $\mathrm{SD}(1)=$ Strongly Disagree}

As shown in Table 3. Teachers were asked to indicate their views on head of departments supervising teaching activities. The findings indicate that majority of teachers disagree that head of departments in secondary schools check teachers' preparation of scheme of works and lesson plans 222(77.1\%), check teachers' lesson notes 134(46.5\%), visit to the classroom to observe teachers lesson presentation and issuing confidential feedback 208(72.2\%), ensure teachers accomplishment of syllabus on time 157(54.5\%), check students' exercises to find out teachers' output of work $146(50.7 \%)$, inspect pupils' assessment record books to find out how teachers make use of continuous assessment records 110(38.2) and holding meeting for teaching evaluation together with teachers 143(49.75\%).

Generally the findings from teachers on the extent academics and head of departments supervise teaching activities suggests three aspects; first imply that head of schools delegates supervisory responsibilities to their subordinates to simplify the leadership loads. The findings is in agreement with Bakhda, (2010) who state that delegation of duties has something to do with giving a top leader an opportunity of reducing workload and become the overall supervisor and performance of other leaders under him or her. In fact head of schools have a lot of duties to perform, so it is difficult for them perform all duties on their own, and if they do they would be limiting the fact of good performance and leading to less effective. In leadership principles delegation of power is important for an effective leader to inspire the abilities and skills of subordinates. From this finding the study may conclude that head of schools in secondary schools are effective in relation to delegation of supervisory roles to their immediate supervisors.

The findings of the study imply that academic masters in secondary schools perform effectively their responsibilities of supervising the daily teaching activities as indicated by teachers. Table 3 teachers indicated that academic masters perform all duties effectively, which can be indicating the possibility of promoting teachers professional commitment in secondary schools. It may also imply that head of schools create conducive environment to academics to perform their roles soundly. This is in line with URT, (2010) which directs responsibilities of academic masters to assist head of schools in supervisory roles on duties of ensuring prepared schemes of work, lesson plans, lesson note, and others. However, this cannot be achieved out of leaders' will. The findings tend to suggest the fact that academics in schools once delegated to the academic office are automatically obliged to dealing with academic matters of students, teachers and schools at large. This position further demands academics to supervise ways teachers are preparing to teach, in terms of observing scheme of works. Lesson plans, lesson notes and effective ways of teaching. However, the study was limited from investigating the level of mandatory academics have to provide necessary teaching materials to teachers, which might affect their effectiveness in relation to fostering teachers professional commitment.

The findings in Table 3. Further Shows majority of respondents disagreed with all the items given that head of department do not supervise their teaching activities. The findings may imply that head of departments are not delegated the supervisory roles in the subjects they lead or their performance is poor. It may also indicate that head of departments are not aware of what are their responsibilities. This findings tend to confirm what was found out by several other studies like Jaca, (2013), Urio, (2012), Plessis, (2014) and Manaseh, (2016). These studies established that head of department knowledge and ability of influencing teachers profession was limited. They could not manage subjects they were expected to supervise and that they lack leadership and management skills. Further studies indicated lack of involvement of head of departments in curriculum development and decision making in school management. This studies may also indicate the issue of ineffective communication and relationship between head of schools and head of departments. It must be noted that, the important role of heads of department in fostering teachers' commitment should not be ignored. Heads of departments can be used by head of schools as a linking factor between head of schools and teachers in class activities. 
Supervising teaching activities in secondary schools is the most factor as far as teachers' commitment is concerned. Therefore, from this findings one has to believe that teachers would be committed to their teaching profession as far as supervision roles from head of schools and academic masters is performed. In line with teachers' information, it was necessary to find out the more information from academic masters/mistress themselves on whether they accomplish their responsibilities of supervising teachers' teaching activities. To achieve this academics were required to point out whether supervision in school were; Always, Frequently, Occasionally, very rarely, or never done in their schools. Table 4. represents the results of academics who participated in this study.

Table 4. Responses of Academic Masters on Supervision of Teachers' Teaching Activities in Secondary Schools $(N=32)$

\begin{tabular}{|c|c|c|c|c|c|}
\hline Responsibilities of Academic masters/mistress & $\mathbf{N}$ & $\mathbf{R}$ & $\mathbf{O}$ & $\mathbf{F}$ & $\mathbf{A}$ \\
\hline $\begin{array}{l}\text { Check teachers' preparation documents (scheme of } \\
\text { work and lesson plans). }\end{array}$ & - & - & - & $14(43.8)$ & $18(56.3)$ \\
\hline Check teachers' lesson notes. & - & - & - & $6(18.8)$ & $26(81.3)$ \\
\hline Observe teachers ways teaching process & - & $5(15.6)$ & $16(50.0)$ & $11(34.4)$ & - \\
\hline $\begin{array}{l}\text { Observe teachers' attendance and punctuality in } \\
\text { school and class attendance. }\end{array}$ & $3(9.4)$ & $2(6.3)$ & $6(18.8)$ & $11(34.4)$ & $10(31.3)$ \\
\hline $\begin{array}{l}\text { Check pupils' exercises to find out teachers' put of } \\
\text { work. }\end{array}$ & $4(12.5)$ & $7(21.9)$ & $6(18.8)$ & $8(25.0)$ & $7(21.9)$ \\
\hline Observe teachers and students relationship & $2(6.3)$ & $6(18.8)$ & $7(21.9)$ & $11(43.4)$ & $6(18.8)$ \\
\hline Observe teachers behaviors & $1(3.1)$ & $5(15.6)$ & $3(9.4)$ & $17(53.1)$ & $6(18.8)$ \\
\hline Record and keep teachers discipline book (s) & $2(6.3)$ & $7(21.9)$ & $9(28.1)$ & $10(31.3)$ & $4(12.5)$ \\
\hline
\end{tabular}

Source: Flied Data 2018

$A(5)=A$ lways,

$N(1)=$ Never

$O(3)=$ Occasionally,

The findings in Table 4. concur with the responses given by teachers in table 4.6 who indicated that academic masters/mistress accomplish their responsibility of supervising teaching activities in secondary schools effectively. It indicate that academics in secondary schools normally perform daily supervisory role for teaching activities in different ways. For example; majority indicate that always they check teachers' preparation documents (scheme of work and lesson plans) 18(56.3\%), check teachers' lesson notes 26(81.3\%), and frequently observe teachers ways teaching process $11(34.4 \%)$, observe teachers' attendance and punctuality in school and class attendance $11(34.4 \%)$, observe teachers and students relationship 11(43.4\%), observe teachers behaviors $17(53.1 \%)$, record and keep teachers discipline book (s) 10(31.3\%) and ensure teachers accomplishment of syllabus on time $8(25.0 \%)$.
The findings tend to suggest the same responses obtained from teachers that, academic in secondary schools are effective in supervising teachers teaching activities for looking at schemes of work, lesson plans lesson notes and teaching activities at large. Findings from academics also indicated that $16(50.0 \%)$ participants were unsure with observing teachers ways of teaching process in classroom. Enike, Eyiene, \& Mercy (2015) observed that supervisory practice of classroom observation enhance teachers' performance and role effectiveness. The circumstances of academics not observing teaching process in classrooms might undermine both the effectiveness of academics and or teachers teaching effectiveness and commitment. However, the findings on this aspect may imply that academic masters could be limited in performing some roles. For example providing teachers with required teaching materials like; text books, teaching aids, chocks, pens, and so on; this could not be fulfilled due to insufficiency resources and funds which has been a common problem to our schools. They could also be overwhelmed with lots 
of roles including teaching. This can limit them from accomplishing other duties as observed in the findings above.

Findings from teachers and academic masters imply that schools had effective head of schools and academics, certainly, effective teaching process and committed teachers, regardless of miner matters issues observed.

In line with the data above, interview with head of schools on the other hand was conducted. It sought to find out the understanding of head of schools on the aspect that their leadership is utmost factor to influence teachers' commitment in their teaching professional. Responses from all participants pointed out that it is their responsibility to ensure that teachers are working accordingly and students are performing well. For example, one head of school said;

"Of course, it is my responsibility to ensure that teachers are at school at the required times, are teaching well, and preparing teaching documents for class presentation. So, at the level of school head teachers have a unique position which demands effective performance of a school. But there is no way I can achieve this in absence of teachers, and not only teachers but also committed one. So it is my responsibility make them committed."

The researcher posed a probe question on what are the responsibilities of head of schools in fostering teachers' teaching commitment in secondary schools. Responses indicate that head of schools seem not have common roles to all schools, because every head mentioned responsibilities different from the other. The responsibilities mentioned include; supervise teaching activities of teachers, advice teachers when is needed, assign workloads and ensure every teachers' attendance at school and in the classroom. When they were asked if they fulfill the mentioned responsibilities effectively, some agreed while others seem not to be sure. One respondent said;

"You know the problem is that I have a lot to do here ate school and outside the school, issues like meetings, and nowadays we have meetings with several leaders almost every week or twice a week. When I come back to school I have many things to plan and monitor, every time there is a knock on my office; students, parents, teachers and so on. It is difficult to give attention on teachers all the time, and in this case I hand over this responsibility to second master or academic and I am sure they do well."
The responses from the above interview tend to suggest that head of schools delegating duties to their immediate supervisors cannot be disregarded. This indicates what Ruto, (2011) said that normally head of schools have complex leadership roles, which demands them to share their responsibilities with others in schools under delegation principle. Other participants from interviews had a bit contradicting understanding, as they consider supervising teachers all the time as disturbing them. Like the one who said;

"I do not have to supervise teachers all the time because I know teachers are mature and they know what they must do as employers, and once I know they are at school, I know they are teaching."

This opinion given from the above response concur with a study by Azi \& Azi (2016) conducted in Nigeria on job satisfaction for teachers, which suggest that teachers need less supervision as longer as they are satisfied with their job and needs, it is possible to perform their duty willingly abiding to their professional requirements. However, for the case of job satisfaction in our area would require further investigation.

For the case of supervising teachers' teaching activities, head of schools were asked, how they supervise and monitor the teaching process. Majority of participants mentioned the way they supervise teaching activities as; Checking preparation documents like scheme of work and lesson plan., Check students excise books to see if teachers are giving exercise and mark them, Teachers must sign class journals every time when they attend classes and teach, they write down what they have covered; a topic, subtopic or other activities done by that day, Every Friday all preparation documents are collected to the office of head of school to see the work done by teachers throughout the week and what have been covered and Pass around during period hours to see if teachers attend classes and if they are teaching well. But this is rarely done because most of head of schools seem to have lot of works, in relation to what has been mentioned by one of head of school above, so they seem not to have enough time of observing what is taking place in classrooms during class hours, as they said they fail to do that because of minimal time.

The researcher was eager to know what measures head of schools take just in case a teacher is not preparing teaching documents or is inefficient. Responses show that normally, for those who are lazy to prepare, and not performing their duties accordingly, are called and warned, sometime by 
warning letter and if they do not change further measures take place.

"For teachers who are not doing well because of not mastering the subjects they teach, or being lazy we just keep eye on them to see if can improve and if not we just report to DEO for further measures."

Supervision of teachers teaching activities is outlined as one among the important element of determining a transformational leader (Hughes, 2014). These findings therefore indicates that head of school possesses this value of being transformational leaders as they fulfil this responsibility of supervising and monitoring teachers' work. In performing this responsibility, sometimes academic masters are assigned to perform this duty as it was previously mentioned that head of schools are sometimes overwhelmed with lots of work. This in contrary might undermine the effectiveness of head of schools in case they lack the ability of keeping an eye tacking on teachers work, unless they build ability of delegating power to teachers who are capable in performing these responsibilities effectively.

The findings from all teachers, academic masters and head of schools were further supplemented with documents observed from schools. The researcher sought to have a look on logbooks, scheme of works, lesson plans, class journals, and continuous assessment report.

Documents indicate that supervision is being done by head of schools and academic masters. Preparatory document used by teachers are mostly adequate used and supervised. For example, logbooks scheme of work, lesson plans and class journals are mostly adequate used. According to
MoEVT, (2013) head of schools are responsible in ensuring proper record keeping mechanism of preparatory documents, in terms of supervision and monitoring teachers teaching works. This is adhered according to the data above. However, majority of schools were not sure if assessment report and syllabus report are available, as they were not available at all and when they were asked why there was no such documents, respondents said, they do not have such system of giving syllabus report, few of them said reports were not yet prepared. This might indicate the weaknesses of head of schools in that area, because the stipulated roles from MoEVT, (2013) keeping proper records and giving reports on time is mandatory to ensure that the curriculum is implemented according to current regulations, lessons are taught, tested, marked, and returned to students and teachers make corrections, which demand continuous assessment reports. Therefore, attention on this area should be improved for future education needs.

\section{Hypothesis Testing:}

The literature used in this study indicated that supervision of teaching activities is among the factors which indicates the effectiveness of school heads in fostering teachers' professional commitment. Hypothesis was developed to test a significant relationship between school heads effectiveness and teachers' professional commitment. The hypothesis stated that:

Ho: There no significant relationship between school headship' effectiveness and teachers' level of commitment in secondary schools.

Table 5. Below presents the relationship between school headship effectiveness and teachers' teaching professional commitment

\begin{tabular}{|c|c|c|c|}
\hline \multicolumn{2}{|l|}{ Statistics } & Mean & Std. Deviation \\
\hline \multicolumn{2}{|l|}{ school leadership effectiveness } & 4.07 & .780 \\
\hline \multicolumn{2}{|l|}{ teachers commitment } & 4.62 & .356 \\
\hline & & correlations & \\
\hline & & $\begin{array}{ll}\text { school } & \text { leadership } \\
\text { effectiveness } & \end{array}$ & teachers commitment \\
\hline $\begin{array}{ll}\text { school } & \text { leadership } \\
\text { effectiveness } & \end{array}$ & $\begin{array}{l}\text { Pearson } \\
\text { Correlation }\end{array}$ & 1 & $.680^{* *}$ \\
\hline
\end{tabular}




\begin{tabular}{|l|l|l|l|}
\hline \multirow{7}{*}{} & Sig. (2-tailed) & & .000 \\
\cline { 2 - 5 } & $\mathrm{N}$ & 288 & 288 \\
\hline \multirow{5}{*}{ teachers commitment } & $\begin{array}{l}\text { Pearson } \\
\text { Correlation }\end{array}$ & $.680^{* *}$ & 1 \\
\cline { 2 - 4 } & Sig. (2-tailed) & .000 & 288 \\
\cline { 2 - 4 } & $\mathrm{N}$ & 288 & \\
\hline \multirow{2}{*}{$* *$ Correlation is significant at the 0.01 level (2-tailed). }
\end{tabular}

Source: Flied Data 2018

Pearson product moment correlation was conducted to determine if there was a significant relationship between headship effectiveness and teachers' teaching professional commitment. Table 5. Show responses from participants indicating that, school heads in secondary schools are effective with $M=4.07 \quad(S D, .78)$ and teachers' teaching professional commitment $M=4.62(S D=.356)$. The Table also indicate that the relationship between headship effectiveness and teachers teaching professional commitment is strong $(r=.680$, $n=288)$ and the correlation coefficient is very high significantly with $(P<0.000)$. These findings means that the effectiveness of headship in schools, supervising and monitoring teaching activities is an important factor in fostering teachers teaching professional commitment, in terms of preparing teaching document, attending classes, effective teaching in schools.

\section{Conclusions:}

The findings of the study indicated that heads of school are "effective" in performing supervisory responsibilities well. Findings show that heads of school normally check teachers' preparations of scheme of works, lesson plans, students notes and visit to the classrooms to observe teachers lesson presentation and issuing sound feedback, observe teachers' attendance and punctuality in school and class attendances, check students' exercises to find out teachers' output of work, inspect pupils' assessment record books to find out how teachers make use of continuous assessment records, visits to the students play grounds and other extra curricula activities, keep teachers' attendance/log books, ensure teachers accomplishment of syllabus on time, give evaluation feedback to teachers and holding meeting for teaching evaluation together with teachers. Head of schools on the other hand mostly delegates supervisory responsibilities to their immediate supervisors like academic masters/mistress to supervise the daily teaching activities. Academics also perform the supervisory role effectively.

The findings on the other hand showed that academic masters have no influence on teachers teaching commitment as the study show that head of departments despite of their significant on the subjects they lead, but they do not supervise teachers' teaching activities. The study revealed also that head of schools are overwhelmed with many responsibilities out and inside schools, which limits their time and ability of dealing with teachers upright. They also not delegate power or responsibility to head of departments in supervisory roles of supervising teachers teaching activities.

\section{Recommendations:}

i. The study recommended that head of schools need to recognize the importance of heads of department in secondary school and delegate them power of supervising teachers works on their subjects and stipulate their roles to enhance effective supervision at the school level.

ii. The study recommended that head of schools should develop strong techniques and skills to manage effectively headship roles especially supervision of teaching activities in their schools by utilizing effective supervisory strategies that works well in their schools.

iii. The Ministry of Education and top leaders in education should give full mandate to heads of school to deal with teachers who fail to observe teaching profession without distraction and long process. This would increase their accountability to head teachers. Issues like punishment in case of any misconducts, teachers' professional development and incentives for teachers 
who performs well could be handled at school level.

\section{References:}

[1] Amani, J. (2014). Factors associated with career choice and predictors of career intention among undergraduate students in Tanzania and career aspirations in Eldoret west district, Kenya. (Doctoral Thesis).Journal of Emerging Trends in Educational Research and Policy Studies (JETERAPS), 4(2), 383-391.

[2] Asuga, G., Eacott , S., \&Scevak , J. (2015). School leadership preparation and development in Kenya.International Journal of Educational Management.29 (3), 355- 367.

[3] Aydin, A. sarier, Y \&Uysal, S. (2013). The Effect of School Principals' Leadership Styles on Teachers' Organizational Commitment and Job Satisfaction.Educational Sciences: Theory \& Practice. 13(2), 806-811.

[4] Balyer, A. \&Özcan, K. (2014).Choosing Teaching Profession as a Career: Students' Reasons.International Education Studies.7 (5).

[5] Benegro, S. (2016) A viable solution to implement effective instructional supervision. Journal of Education and Learning. 5 (1).

[6] Betweli, O. (2013). The nature of teacher professional misconduct in Tanzania public primary schools: The case of Sumbawanga Municipality and Rural Districts. International Journal of Education, 5(1), 81-93.

[7] Blaikie, N. (2000). Designing social research: The logic of anticipation. Cambridge, UK: Polity.

[8] Blasé, J. \& Blasé, J. (2000). Effective instructional leadership: Teachers' perspectives on how principals promote teaching and learning in schools. Journal of Educational Administration.38 (38), 130-136.

[9] Campbell, J. Kyriakides, L. Muijs, D. \& Robinson, W. (2012).Assessing teacher effectiveness: Different Models.Routledge: London and New York.

[10] Chadwick, H. (2001). Organizational research: Determining appropriate sample size. Information Technology and Performance Journal. 19 (1), 43-50.

[11] Chen, Y., Cheng, J. \& Sato, M. (2016).Effects of school principals' leadership behaviors: A comparison between Taiwan and Japan. Educational Sciences: Theory \& Practice. 17 (1), 145-173.
[12] Creswell, J. W. Clark, V. L. P. (2011). Designing and Conducting Mixed Methods Research: SAGE: United States of America.

[13] Cyprès, A. Breckner, J. (Eds.). (2013). Great Leaders Equal Great Schools: Alliances and Discourse for Educational Reform. IAP: USA.

[14] Dassan, F. \&Sima, R. G. (2017).The discrepancy between teachers' self and pupils' evaluation on teachers' professional suitability.European journal of research and reflection in educational sciences.5 (2).

[15]

Day, C. \& Sammons P. (2016) Successful school leadership: Education Development trust. University of Nottingham: Malaysia.

[16] Duze, C. O. (2012). The Changing role of school leadership and teacher capacity building in teaching and learning.Journal of Emerging Trends in Educational Research and Policy Studies. 3 (1), 111-117.

[17] Emmanouil, K., Osia, A. \&ParaskeviIoanna, L. (2014).The impact of leadership on teachers' effectiveness.International Journal of Humanitiesand Social Science.4, 7(1) 34-39. www.ijhssnet.com/journals.

[18] Gebreselassie, M. (2015).Principals' roles in fostering teachers' continuous professional development in government secondary schools of Addis Ababa: (Doctoral dissertation, Addis Ababa University- Ethiopia, 2015).

[19] Graen G. B. \&Uhl-Bien M. (1995). Relationship-based approach to leadership: development of leader-member exchange (LMX) theory of leadership over 25 years: applying a multi-level multi-domain perspective. Leadership. 6(2):219-247.

[20] Gyasi, R.S., Bao Xi, W., \&Ampomah Y. O. (2016).The Effect of Leadership Styles on Learners' Performance: The case of AsonomasoNkwanta in the Kwabre District Assembly of Ashanti Region in Ghana.Journal of Education and Practice. 7,26.

[21] HakiElimu, (2014).Teaching effectiveness in primary and secondary schools in Tanzania. Dar-es-salaam, Tanzania.

[22] Harris, H. Day, C. Hadfield, M. Hopkins, D. Hargreaves, A. \& Chapman, C. (2013).Effective leadership for school improvement.Roulledge.

[23] Ismail N. A. (2011). Graduates' characteristics and unemployment: a study 
among Malaysian graduates. International Journal of Business and Social Science.2, (16).

[24] Jackson, S., Sakuma, S., \&DeVol, P. (2015). The Complexity in Defining Leadership: How gifted students' backgrounds influence their understanding of effective leadership. Reports - Research. 20 (1), 40-46.

[25] Kalagbor, D. L. (2016).An analysis of factors influencing students' academic performance in public and private secondary schools in Rivers states. Nigeria. Journal of Education and Practice. 7 (28), 96-101.

[26] Komba, W. L. \&Nkumbi, E. (2009) Teacher Professional Development in Tanzania: Perceptions and Practices.CICE Hiroshima University, Journal of International Cooperation in Education. 11( 3), 66-83.

[27] Kuluchumila, R. C. (2014)Preparation and development of secondary school heads: what should be done in Tanzania? British Journal of Education. 2 (2), 9-39.

[28] Kunter, M., Klusmann, U., Baumert, J., Richter, D.,Voss, T. \&Hachfeld, A. (2013) Professional competence of teachers: Effects on instructional quality and student development. Journal of Educational Psychology. 105 (3), 805-820. DOI: 10.1037/a0032583.

[29] Malunda, P. Onen, D.Musaazi, J. C. S. \&Oonyu, J (2016).Instructional Supervision and the Pedagogical Practices of Secondary School Teachers in Uganda.Journal of Education and Practice.7 (30).

[30] Mackatiani, C., Imbovah , M., Imbova, N. \&Gakungai D.K. (2016).Development of education in Kenya: Influence of the politicalfactor beyond 2015 Mdgs. Journal of Education and Practice. 7 (11).

[31] Malekela, G. (2004). Current practices in primary education in Tanzania. In Noah Mtana, EneaMhando and GunillaHojlund (eds.). Teaching and Learning in Primary Education in Tanzania. Dar es Salaam: Ecoplint.

[32] McGinn, N. \& Welsh, T. (199). Decentralization of education: Why, when, what and how? UNESCO: Available from http://www.unesco.org/iiep

[33] Mgonja, M. G. (2017). Responding to workplace absenteeism in Tanzania: The case study of public and private schools in Ilala Municipality and MkurangaDistrict. International Journal of Educational Leadership and Management.5 (1), 85-108.
[34] Mkumbo, K. (2012). Teachers ${ }^{\text {ee }}$ Commitment to and Experiences of the Teaching Profession in Tanzania: Findings of Focus Group Research. International Education Studies, 5(3), 222- 227.

[35] MoEVT.(2007), "Teacher Service Department (TSD)". Dar es Salaam: MoEVT.

[36] Musa, J. (2014). Role of school leadership in motivating teachers: A case of Ilala Municipality, Dar es Salaam. Open University of Tanzania. Available fromhttp://webcache.googleusercontent.com/se arch?q=cache:XcaeKc8oXgwJ:repository.out.ac .tz.

[37] Ofoegbu, F. I. (2014). Teacher Motivation: A Factor for Classroom Effectiveness and School Improvement in Nigeria. Gale Group. Retrieved June, 2017 from http://www.findArticles.com.

[38] Prelli, G. E. (2016). How school leaders might promote gigher levels of collective Teacher efficacy at the level of school and team. English Language Teaching; Canadian Center of Science and Education.9 (3).

[39] Rahmatullah R. (2016). The relationship between learning effectiveness, teacher competence and teachers performance madrasah Tsanawiyah at Serang, Banten, Indonesia. Higher Education Studies. 6 (1).

[40] Rajbhandari, M. M. S. (2014). Critical perspective on Situational leadership theory: Leadership Readiness for Flexibility and Mobility. The 4th Dimensions on Situational Leadership styles in educational settings. ED552915. Retrieved from http://eric.ed.gov/PDFS/ED532213.pdf

[41] Sarier, A. Aydin, Y. \&Uysal, S. (2013). The Effect of school principals' leadership styles on teachers' organizational gommitment and job satisfaction. Educational Sciences: Theory \& Practice; 13 (2), 806-811.

[42] Sesay, A. (2014). African governance systems in the pre and post-independence periods: Enduring lessons and opportunities for youth in Africa.Discussion Paper for The Mandela Institute for Development Studies, Johannesburg.

[43] Songela A. M. (2015). The effectiveness of teacher's service department in promoting secondary school teachers' moral and ethical values in Tanzania: A case of Rufiji District Council. Mzumbe University. Available from; scholar.mzumbe.ac.tz/bitstream/handle//MSc_ HRM 
[44] Supovitz, J. (2014). Building a lattice for school leadership: The top to bottom rethinking of leadership development in England.Thomas B. Fordham Institution.Available from http://edexcellence.net/commentary/videos/vid eo-leadership-evolving-new-models-ofpreparing-school-heads.

[45] The United Republic of Tanzania (1995).Educational Training Policy. Dar es Salaam: Ministry of education and culture

[46] The United Republic of Tanzania (2014). Basic Education Statistics in Tanzania (BEST), Dar essalaam: MoEST

[47] The United Republic of Tanzania (20122016). Ministry of education, science and technology: Basic Education Statistics in Tanzania (BEST). National Data.

[48] Twaweza, (2013). Form Four Examination Results: Citizens report on the learning crisis in Tanzania.

Sautiyawananchi.uwazi@twaweza.org www.twaweza.org/sauti

[49] Uwezo (2015) Does Teacher Availability Matter? Evidence from Uwezo East Africa Study Data.Journal of Contemporary Issues in Education. 10 (1), 46-60.

[50] Uwezo (2016) Are our children learning? Uwezo Kenya sixth learning assessment report. Nairobi: Twaweza East Africa. www.twaweza.org / www.uwezo.net

[51] Uysal, S., Aydin, A. \&Sarier, Y. (2013).The effect of school principals' leadership styles on teachers' organizational commitment and job satisfaction. Educational Sciences: Theory \& Practice. 13 ( 2), 806-811.

[52] Walumbwa, F.O., Mayer, D.M., Wang, P., Wang, H., Workman, K., Christensen, A.L., (2011). Linking ethical leadership to employee performance: the roles of leader- member exchange, self-efficacy, and organizational identification. Organizational Behavior and Human Decision Processes 115, 204-213

[53] Wolhuter, C. Walt, H.\&Steyn H. (2016).A strategy to support educational leaders in developing countries to manage contextual challenges.South African Journal of Education, 33 (4).

[54] Zaka, p. (2013) A case study of blended teaching and learning in a New Zealand secondary school, using an ecological framework. Journal of Open, Flexible, and Distance Learning. 1 (1).
[55] Zeichner, K. \& Liston, D. (2013). Reflective teaching: An Introduction. Hoboken, NJ: Taylar\& Francis.

[56] Zhang, Z., Wang, M., Shi, J., 2012. Leaderfollower congruence in proactive personality and work outcomes: the mediating role of leader-member exchange. Academy of Management Journal 55, 111-130. 